\title{
Preparation and Evaluation of Granola - a Breakfast Cereal, Sustituted with Maize (Zea May) and Coconut (Cocos Nucifera) Blend
}

\author{
Eke - Ejiofor Joy ${ }^{*}$, Beleya Ellen Aswei, Gbarasogo Mbarabari Nicholas \\ Department of Food Science and Technology, Rivers State University of Science and Technology Nkpolu, Port Harcourt, Nigeria
}

Email address:

joyekee@yahoo.co.uk (Eke - Ejiofor J.)

\section{To cite this article:}

Eke - Ejiofor Joy, Beleya Ellen Aswei, Gbarasogo Mbarabari Nicholas. Preparation and Evaluation of Granola - a Breakfast Cereal, Sustituted with Maize (Zea May) and Coconut (Cocos Nucifera) Blend. International Journal of Nutrition and Food Sciences. Vol. 5, No. 1, 2016, pp. 47-52. doi: 10.11648/j.ijnfs.20160501.17

\begin{abstract}
Granola was produced using three varieties of maize namely, yellow, white and pop and oat as control. Coconut was added to the granola sample in order to replace walnut in the control. They were subjected to sensory, chemical and functional evaluation. Sensory analysis showed that there was significant difference in their color and taste, while flavor, texture, crispness and overall acceptability showed no significant difference $(p \geq 0.05)$. Chemical analysis result showed that oat based granola had the highest value for fat, protein, energy, sugar, starch and amylopectin, while yellow maize granola had the highest value for moisture content and carbohydrate and white maize granola had the highest value for crude fibre and amylose. Granola produced from pop maize had the highest value for ash. There was no significant difference ( $\mathrm{P} \geq 0.05)$ in ash, protein energy and amylopectin between oat granola (control) and maize based granola samples. Functional analysis of the samples showed that oat granola had the highest value for water absorption capacity and swelling power. Yellow maize granola had the highest value for dispersibility and bulk density. Pop corn granola had the highest value for solubility. There was no significant difference $(\mathrm{P} \geq 0.05)$ in bulk density and water absorption capacity.
\end{abstract}

Keywords: Granola, Substitution, Preparation, Evaluation, Maize, Coconut, Breakfast - Cereal

\section{Introduction}

Granola is a ready-to-eat breakfast cereal that is made from grain typically high in carbohydrate, low fat and often a good source of fibre (Annelisse, 2009). It is a breakfast food made from oats, walnut, peanut and wheat which is usually baked until it is dry and crisp. A breakfast cereal therefore can be said to be a ready to cook, ready to eat convenient food product. They include puffed, flaked, shredded and granular products made from wheat, maize, oats, rice and barley. They may be enriched with sugar, honey, a malt extract and fortified with vitamins, minerals and nutrients (Annelisse, 2009).

Besides serving granola as food for breakfast, it is also eaten by those who are hiking or camping because of it lightweight and high calories. Granola is often eaten with yoghurt, honey, fruit and milk. It can also serves as topping for various types of pastries and/or dessert.

Oat and walnut are the main raw materials for the production of granola, which is relatively high in cost due to the fact that it is not grown in Nigeria. Granola is unpopular and therefore its consumption is very low and so stands the status of a smuggled product from Ghana where it is more of a staple food. There is little information in literature on the product granola and therefore this research.

Maize which is locally available and of low cost may serve as a substitute for oat and coconut for African walnut in the production of substitute granola. It is the most widely grown crop (FAO, 2009) and the fourth most consumed cereal in the past two decades, below sorghum, millet and rice (FAOSTAT 2012). Being among the primary food staples, maize consumption is widespread across the country and among households of different status. It is widely used in the preparation of traditional foods, and has two major types, white and yellow with a high content of carbohydrate, moderate protein (zein), fat, but rich in fibre, mineral and vitamin. Its protein contains low amount of gluten but a good source of starch which is used for baking and its oil used for cooking (Watson 1987). 
In Nigeria, coconut is grown mainly for food and wholly eaten raw, until recently when it is being processed on a small scale into candies and chips (Asiedu, 1989). Coconut has various uses and its flour has been developed for use in baking to combat malnutrition (Grinwood, 1975). It is used as a source of sugar, dietary fibre, protein, antioxidant and vitamin (Paniappan, 2002). The coconut residue is made into flour (Timida et al., 2001) and believed to contain dietary fibre, which has an important health implication in the prevention of risk of chronic disease such as cancer, cardiovascular disease and diabetes. Studies revealed that consumption of high coconut flour increase fecal bulk (Arancon, 1999). Coconut flour is gluten-free, though contain a significant protein. Its flour is used as composite in the baking of some product to improve the nutritional composition. According to Barret et al., (2004) when coconut flour is incorporated into wheat flour, it increases the amino acid content especially lysine.

Peanut flour/paste remains underutilized and research is needed to develop new value added products from this raw material that is mainly used for livestock. Peanut has assumed significance in the recent years as a protein source in diets due to its high proteins content $(25.80 \%)$. Its meal can be dried and ground into a paste form that can be added to various daily consumed foods (Zhao et al., 2011).

Continuous search for wholesome food and poor nutritional quality of most readily available breakfast meal have lead to the utilization of other cheap underutilized and available food raw material which are desirable in reducing the use of high cost raw material such as oat and wheat to further enhance product development. This research intends to develop an adequate and nutritionally enriched breakfast meal to meet the need of the teeming population of our society. The objectives of this study therefore are, to prepare granola from locally available raw materials such as maize, coconut and peanut and to evaluate the sensory, chemical and functional properties of the granola samples.

\section{Materials and Methods}

\subsection{Materials}

Maize (Zea may), oat (Avena sativa), peanut (Arachis hypogaea), coconut (Cocos nucifera), wheat (Triticumspp), milk, sugar, vegetable oil and vanilla flavor were Purchased from Mile 3 Market, while African walnut was purchase from "Spar" supermarket, all in Port Harcourt, Rivers State, Nigeria.

\subsection{Chemicals}

Chemicals used for this analysis were of analytical grade and were all obtained from the Biochemistry laboratory, Department of Food Science and Technology, Rivers State University of Science and Technology, Port-Harcourt, Rivers State, Nigeria.

\section{Methods}

\subsection{Preparation of Maize Meal}

Maize grain (white, yellow and pop) varieties were sorted to remove spoilt grains. They were cleaned, winnowed and milled using a dry milling machine. The meal obtained were then stored in an air-tight container for use in the preparation of granola.

Maize(yellow, white and pop varieties)

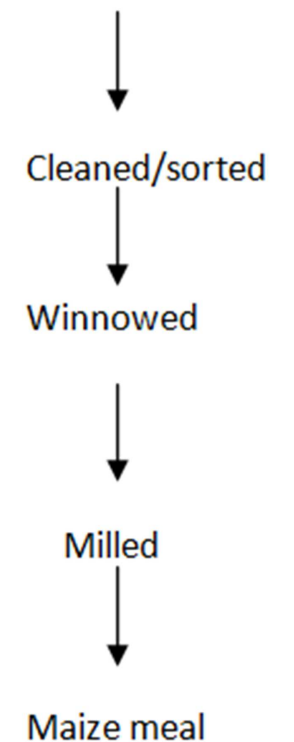

Source: Adapted from Houssou and Ayemor, (2002).

Figure 1. Flowchart for the production of maize meal.

Table 1. Recipe for the production of granola.

\begin{tabular}{lll}
\hline Ingredients & Quantities & \\
\hline & Standardgranola & Alternativegranola \\
\hline & (control) & \\
\hline Oat & $500 \mathrm{~g}$ & $\overline{500 \mathrm{~g}}$ \\
Maizemeal & - & - \\
AfricanWalnut & $80 \mathrm{~g}$ & $80 \mathrm{~g}$ \\
Coconutmesh & $-160 \mathrm{~g}$ & $160 \mathrm{~g}$ \\
Groundpeanut & $100 \mathrm{~g}$ & $100 \mathrm{~g}$ \\
Wheatflour & $160 \mathrm{~g}$ & $160 \mathrm{~g}$ \\
Sugar & $200 \mathrm{ml}$ & $200 \mathrm{ml}$ \\
Water & $16 \mathrm{ml}$ & $16 \mathrm{ml}$ \\
Vegetableoil & $4 \mathrm{ml}$ & $4 \mathrm{ml}$ \\
Vanillaflavor & & \\
\hline
\end{tabular}

Source: George and Esther, (2003).

\subsection{Preparation of Granola}

Granola was prepared according to the method described by George and Esther, (2003). Maize meal, coconut mesh, ground peanut, wheat flour and sugar were weighed into a bowl and mixed. Water, vegetable oil and vanilla flavor were added to the weighed sample in the bowl and were mixed into dough kneaded and cut into shape. The dough was spread on the tray and baked in an oven at $130^{\circ} \mathrm{C}$ for one hour. The baked product (granola) was allowed to cool and subsequently store in an airtight container. 


\subsection{Sensory Evaluation}

Granola samples were subjected to sensory evaluation within 24 hours of production. The granola was evaluated in two forms; dry and in milk solution the form in which it is to be served. A uniform quantity of granola and milk/sugar solution were given to all panelists in order to provide a base for assessment.

The dry sample was evaluated for color/appearance, crispness, aroma, taste, texture and overall acceptability while granola in milk solution was evaluated for color/appearance, taste, texture/mouthful flavor and overall acceptability.

A questionnaire was used to assess the above mentioned attributes using a 5-point hedonic scale with $5=$ like extremely, 4 = like very much, 3 = neither like nor dislike, 2 = dislike very much, 1 = dislike extremely (Larmond 1977). Twenty (20) semi trained panelists drawn from within and outside the Department of Food Science and Technology, who are regular consumers of maize and coconut and who were neither sick nor allergic to any component of the raw material used for the production of the products at the time of the evaluation, were involved in the assessment. The panelists were instructed to rinse their mouth with water after tasting each granola sample.

\subsection{Statistical Analysis}

Results were statistically analyzed by using analysis of variance technique. Level of significance within means was calculated by using the Duncan Multiple Range Test (Steel and Torrie, 1980).

\subsection{Chemical Analysis of Granola Samples}

The chemical analysis of granola samples was determined using the AOAC (1990) methods for moisture, ash, protein, fat and fibre. Total carbohydrate was calculated by difference of moisture, ash, protein, fat and fibre. The total energy value of the samples was determined according to the method described by Mahgoub (1999). Amylose content was determined according to the method described by Williams et al., (1970), while amylopectin was calculated by difference (\% Amylopectin $=\%$ starch - \% amylose). Starch and sugar was determined by the method described by Eke 2006 .

\subsection{Functional Properties}

Dispersibility was determined by the method of Kulkarni et al., (1991), while the relative bulk density of samples was determined by the method described by Narayana and Narasinya, (1984). The water absorption capacity was determined using the method by Sosulski, (1962) while swelling Power and Solubility was determined using the method of Takashi and Sieb, (1988).

\section{Results and discussions}

\subsection{Sensory Evaluation Result of Granola}

Table 2 shows the sensory evaluation result of dry granola samples prepared from three different maize varieties namely white, yellow and pop corn.

Color ranged from $2.00-4.15$ with samples C and D (pop and yellow maize granola, respectively) as the most preferred, while taste ranged from $2.90-4.15$ with sample A (control) having the highest score. Color and taste are important sensory attributes which to a large extent determines the acceptability of food products. In the present study color and taste showed a significant difference $(p<0.05)$ between the control and the maize based products. Flavor ranged from $3.10-3.30$ with sampleD (yellow maize) as the highest, while texture had 3.30 for sample A (control), $\mathrm{B}$ (white maize) and C (pop corn maize) and 3.55 for sample $\mathrm{D}$ (yellow maize), with no significant difference occurring in texture. Crispness ranged from $3.30-4.00$ with sample C (popcorn) having the highest. Overall acceptability ranged from 3.35 - 3.60 with samples A (control) and C (popcorn) as the highest. Flavor, texture, crispness and overall acceptability showed no significant differences $(p>0.05)$ amongst the samples. This suggests that acceptable granola can be produce from the combination of maize, coconut and peanut.

Table 2. Sensory evaluation result of dry granola samples.

\begin{tabular}{lllllll}
\hline Sample & Color & Taste & Flavor & Texture & Crispness & Overall Acceptability \\
\hline A & $2.00^{\mathrm{a}} \pm 0.92$ & $4.15^{\mathrm{a}} \pm 1.14$ & $3.20^{\mathrm{a}} \pm 1.51$ & $3.30^{\mathrm{a}} \pm 1.45$ & $3.45^{\mathrm{a}} \pm 1.19$ \\
$\mathrm{~B}$ & $3.30^{\mathrm{b}} \pm 0.94$ & $3.05^{\mathrm{b}} \pm 1.09$ & $3.10^{\mathrm{a}} \pm 1.09$ & $3.30^{\mathrm{a}} \pm 1.22$ & $3.30^{\mathrm{a}} \pm 1.03$ \\
$\mathrm{C}$ & $4.15^{\mathrm{a}} \pm 0.88$ & $2.90^{\mathrm{b}} \pm 1.16$ & $3.25^{\mathrm{a}} \pm 1.16$ & $3.30^{\mathrm{a}} \pm 0.98$ & $4.00^{\mathrm{a}} \pm 0.85$ & $3.55^{\mathrm{a}} \pm 0.99$ \\
$\mathrm{D}$ & $4.15^{\mathrm{a}} \pm 1.99$ & $3.55^{\mathrm{a}} \pm 1.31$ & $3.30^{\mathrm{a}} \pm 1.08$ & $3.55^{\mathrm{a}} \pm 1.28$ & $3.30^{\mathrm{a}} \pm 1.17$ & $3.30^{\mathrm{a}} \pm 0.95$ \\
\hline
\end{tabular}

Means with the same superscript in the same column are not significantly different $(\mathrm{P}>0.05)$.

Key: A= Oat granola (control).

$\mathrm{B}=$ white maize granola.

$\mathrm{C}=$ popcorn granola.

$\mathrm{D}=$ yellow maize granola

\subsection{Sensory Evaluation of Granola in Milk/Sugar Solution}

Table 3 shows the sensory evaluation result of granola samples consumed in a given quantity of milk and sugar in the ratio 3: 1, weight for weight. Color/Appearance ranged from $2.70-4.05$ with sample $\mathrm{D}$ (yellow maize) as the highest, while taste, flavor, texture and overall acceptability ranged from $2.95-4.05 ; 3.15-4.05 ; 3.10-3.75$ and from 3.15 - 3.85 with sample A (control) having the highest respectively. 
Table 3. Sensory evaluation result of granola in milk solution.

\begin{tabular}{llllll}
\hline Sample & Color & Taste & Flavor & Texture & Overall acceptability \\
\hline A & $2.70 \mathrm{a} \pm 1.17$ & $4.05 \mathrm{a} \pm 1.09$ & $4.05 \mathrm{a} \pm 0.94$ & $3.75 \mathrm{a} \pm 1.02$ & $3.85 \mathrm{a} \pm 1.09$ \\
B & $3.20 \mathrm{a} \pm 0.95$ & $3.40 \mathrm{~b} \pm 0.94$ & $3.15 \mathrm{~b} \pm 1.18$ & $3.10 \mathrm{a} \pm 1.07$ & $3.20 \mathrm{a} \pm 1.11$ \\
C & $3.50 \mathrm{~b} \pm 1.00$ & $2.95 \mathrm{~b} \pm 1.09$ & $3.25 \mathrm{~b} \pm 0.91$ & $3.40 \mathrm{a} \pm 1.27$ & $3.50 \mathrm{a} \pm 1.24$ \\
D & $4.05 \mathrm{a} \pm 1.24$ & $3.05 \mathrm{~b} \pm 1.31$ & $3.15 \mathrm{~b} \pm 1.34$ & $3.10 \mathrm{a} \pm 1.37$ & $3.15 \mathrm{a} \pm 1.18$ \\
\hline
\end{tabular}

Means with the same superscript in the same column are not significantly different $(\mathrm{P}>0.05)$.

Key: A= Oat granola (control).

$\mathrm{B}=$ white maize granola.

$\mathrm{C}=$ popcorn granola.

$\mathrm{D}=$ yellow maize granola.

Table 4. Chemical composition of granola (\%).

\begin{tabular}{|c|c|c|c|c|c|c|c|c|c|c|c|}
\hline Sample & M.C & Ash & Fat & $\begin{array}{l}\text { Crude } \\
\text { Protein }\end{array}$ & Crude Fiber & CHO & $\begin{array}{l}\text { Energy } \\
\text { (Kcal/100g) }\end{array}$ & Sugar & Starch & Amy & Amylop \\
\hline A & $5.65 \mathrm{~b} \pm 0.21$ & $1.47 \mathrm{a} \pm 0.09$ & $22.53 a \pm 0.68$ & $10.92 \mathrm{a} \pm 0.96$ & $2.58 \mathrm{~b} \pm 0.14$ & $56.58 \mathrm{~b} \pm 0.01$ & $473.75 a \pm 6.02$ & $11.17 \mathrm{~b} \pm 0.04$ & $80.37 a \pm 0.15$ & $40.11 \mathrm{c} \pm 0.07$ & $40.26 \mathrm{a} \pm 0.07$ \\
\hline B & $6.60 \mathrm{a} \pm 0.00$ & $1.45 \mathrm{a} \pm 0.02$ & $20.69 b \pm 0.83$ & $6.65 \mathrm{a} \pm 0.72$ & $3.91 \mathrm{a} \pm 0.02$ & $60.75 a \pm 0.08$ & $455.32 \mathrm{a} \pm 7.79$ & $10.59 \mathrm{~b} \pm 0.0$ & $74.29 c \pm 0.25$ & $40.66 \mathrm{a} \pm 0.07$ & $33.63 \mathrm{~b} \pm 0.07$ \\
\hline $\mathrm{C}$ & $6.30 \mathrm{a} \pm 1.28$ & $1.53 \mathrm{a} \pm 0.07$ & $18.29 \mathrm{c} \pm 0.06$ & $9.74 \mathrm{a} \pm 0.24$ & $2.06 \mathrm{c} \pm 0.06$ & $60.08 \mathrm{a} \pm 0.08$ & $451.89 \mathrm{a} \pm 0.40$ & $10.84 \mathrm{~b} \pm 0.04$ & $77.35 b \pm 0.50$ & $40.27 c \pm 0.07$ & $37.08 \mathrm{a} \pm 0.07$ \\
\hline $\mathrm{C}$ & $6.75 \mathrm{a} \pm 0.07$ & $1.43 \mathrm{a} \pm 0.07$ & $19.38 \mathrm{c} \pm 1.52$ & $7.18 \mathrm{a} \pm 2.41$ & $3.70 \mathrm{a} \pm 0.21$ & $61.56 \mathrm{a} \pm 0.00$ & $450.19 \mathrm{a} \pm 15.56$ & $11.04 \mathrm{a} \pm 0.04$ & $76.25 b \pm 0.29$ & $40.33 b \pm 0.15$ & $35.92 \mathrm{a} \pm 0.16$ \\
\hline
\end{tabular}

Means with the same superscript in the same column are not significantly different $(P>0.05)$.

Key: A= (control)

$\mathrm{B}=$ White maize granola

$\mathrm{C}=$ Popcorn granola

$\mathrm{D}=$ Yellow maize granola

M.C $=$ Moisture content

$\mathrm{CHO}=$ Carbohydrate

Amy $=$ Amylose

Amylop $=$ Amylopectin

\subsection{Chemical Composition of Granola}

Table 4 shows the chemical evaluation result of granola prepared from three different maize varieties namely white, yellow and pop corn varieties. Moisture content ranged from $5.65 \%-6.75 \%$ with sample A (control) as the least and sample D (yellow maize) as the highest. Moisture content of granola ranging from $5.65 \%$ to $6.75 \%$ is less than the finding of Annelisse (2009) with the $15.1 \%$ with use of resistant starch for production of granola bar. The low moisture content of these products indicates that the product would have an extended shelf life.

Ash content ranged from $1.43 \%-1.53 \%$ with sample D (yellow maize) as the least and sample $\mathrm{C}$ (popcorn) as the highest. This result agrees with the finding of Jeffrey et al., (2011) who reported $1.50 \%$ ash content for corn meal, while fat content ranged from $18.29 \%-22.53 \%$ with sample C (popcorn) as the least and sample A (control) the as highest. Fat content of granola in this study agrees with the findings of Annelisse (2009) with a value of $18.60 \%$. The higher fat content of sample A (control) may be as a result of high fat content of African walnut, which was substituted with coconut, thereby giving a product of less fat content. Fat content may also be influenced by varietal difference

Protein content ranged from $6.65 \%-10.92 \%$ with sample B (white maize) as the least and sample A (control) as the highest. Protein content in this work agrees with the finding of Muhammad et al (2012) with a value of $9.00 \%$ of corn grit. The protein result of sample A (control) with a higher protein content is expected because of the presence of wheat which is known for its high protein, in relation to maize.

Crude fibre result of $2.06 \%$ to $3.91 \%$ agrees with the findings of Muhammad et al., (2012) with a value of 3.91\% for granola bar substituted with native syrup and dietary fibre. This result indicates that maize is a rich source of fibre.

Carbohydrate content ranged from 56.85 - 61.56\% with samples A (control) as the least and sample D (yellow maize) as the highest. This result agrees with the findings of Annelisse (2009) with a value of $58.9 \%$, while energy ranged from $451.89 \mathrm{kcal} / 100 \mathrm{~g}-473.75 \mathrm{kcal} / 100 \mathrm{~g}$ with sample C (popcorn) as the least and sample A (control) as the highest. This result also is in agreement with the findings of Annelisse (2012) with a value of $450 \mathrm{kcal} / 100 \mathrm{~g}$. The result shows that despite the change in the composition of the original ingredients, it did not adversely affect the derivable energy in the new product.

Sugar and starch contents ranged from $10.59 \%$ to $11.17 \%$ and from $74.29 \%$ to $80.37 \%$ with sample B (white maize) as the least and sample A (control) as the highest respectively. There were no significant differences $(\mathrm{P} \geq 0.05)$ in sugar and starch contents of the samples.

Amylose content ranged from $40.11 \%$ to $40.27 \%$ with sample A (oat granola) has the lowest value and sample B (white maize) has the highest value, while the reverse was the case for amylopectin which ranged from $33.63 \%$ to $40.26 \%$ with sample B (white maize) having the least and sample A (control) having the highest. Amlyose is the linear components of starch and it imparts definite characteristics to starch and therefore, its content is an important criterion in 
starch quality (Kurup, 1994). Amylose and amylopectin

samples. showed significant difference $(\mathrm{P} \leq 0.05)$ between the

Table 5. Functional properties of granola samples.

\begin{tabular}{llllll}
\hline Sample & Dispersibility $(\%)$ & Bulk Density $(\mathbf{g} / \mathbf{m l})$ & WAC $(\mathbf{g} / \mathbf{g})$ & Solubility & Swelling Power $(\mathbf{g} / \mathbf{g})$ \\
\hline A & $66.00 \mathrm{~b} \pm 2.82$ & $0.40 \mathrm{a} \pm 0.01$ & $1.04 \mathrm{a} \pm 0.00$ & $23.07 \mathrm{~b} \pm 0.49$ & $5.89 \mathrm{a} \pm 0.18$ \\
B & $71.50 \mathrm{a} \pm 2.12$ & $0.46 \mathrm{a} \pm 0.02$ & $0.96 \mathrm{a} \pm 0.01$ & $23.89 \mathrm{~b} \pm 0.16$ & $4.85 \mathrm{~b} \pm 1.16$ \\
C & $73.00 \mathrm{a} \pm 0.00$ & $0.46 \mathrm{a} \pm 0.00$ & $0.95 \mathrm{a} \pm 0.05$ & $25.18 \mathrm{a} \pm 0.16$ & $4.57 \mathrm{~b} \pm 0.14$ \\
D & $74.50 \mathrm{a} \pm 0.70$ & $0.47 \mathrm{a} \pm 0.00$ & $0.81 \mathrm{~b} \pm 0.00$ & $25.15 \mathrm{a} \pm 1.41$ & $4.92 \mathrm{~b} \pm 0.01$ \\
\hline
\end{tabular}

Means with the same superscript in the same column are not significantly different $(P>0.05)$.

Key: A= Oat granola (control).

$\mathrm{B}=$ white maize granola.

$\mathrm{C}=$ popcorn granola.

$\mathrm{D}=$ yellow maize granola

$\mathrm{WAC}=$ water absorption capacity

\subsection{Functional Properties of Granola}

Table 5 shows the functional properties of granola prepared from three different maize varieties namely white, yellow and pop corn varieties.

Dispersibility and bulk density ranged from $66.00 \%$ $74.50 \%$ and from $0.40-0.47 \mathrm{~g} / \mathrm{ml}$ with sample A (oat granola, control) as the least and sample D (yellow maize) as the highest. Dispersibility in water shows the ease of break-up of agglomerates which allow particles to sink below the surface and disperse rapidly in liquid (Tizazu and Emire 2010), while bulk density is very important in packaging and material handling since it enables a higher amount of material occupy a smaller volume (Karma et al., 1981). There was a significant difference $(\mathrm{P} \leq 0.05)$ between oat based granola and maize based granola in dispersibility and no significant different $(\mathrm{P}>0.05)$ in bulk density amongst the samples.

Water absorption capacity ranged from $0.81-1.04 \mathrm{~g} / \mathrm{g}$ with sample D (yellow maize) as the least and sample A (oat granola, control) as the highest. Niba et al., (2001) described water absorption capacity as an important processing parameter that has implications for viscosity. Furthermore, water absorption capacity is important in bulking and consistency of products. Increase in water absorption capacity in food systems enables end users to manipulate the functional properties of the dough in the bakery products. The yellow maize granola (sample D) was significantly different $(\mathrm{P} \leq 0.05)$ from the other samples.

Solubility ranged from $23.07 \%-25.18 \%$ with sample A (control) as the least and sample $\mathrm{C}$ (popcorn granola) as the highest, while the reverse was the case for swelling power which ranged from $4.57-5.89 \mathrm{~g} / \mathrm{g}$ with sample C (popcorn) having the least value and sample A (control) having the highest value. Solubility reflects the extent of intermolecular cross bonding within the granule (Hari et al., 1989). In agreement with the above statement, Safo-Kantanka et al., (1996) stated that the swelling power of a starch based food is an indication of the strength of the hydrogen bonding between the granules. Swelling power therefore is a measure of swollen starch granule and the food eating quality is connected with retention of swollen starch granules (Richard et al., 1991). Swelling capacity is also a function of the product to rise when having interaction with water. Finney (1994) reported that the swelling capacity affects the temperature at which a product forms gel in maize flour; a similar observation was made in the present study. Solubility and swelling power showed significant difference between the samples.

\section{Conclusion}

Granola can be prepared from maize meal and coconut. The study has shown that maize and coconut can be substituted for oat and walnut in the production of granola of acceptable quality without altering the flavor, texture and crispness of the original oat based product. Maize based granola showed an increased value in carbohydrate, fibre and energy with energy showing no significant difference, while functional properties of the products also showed better dispersibility and solubility of maize based granola. However there was no significant difference in bulk density and water absorption capacity between the maize based granola and the control. Therefore maize and coconut can be used to produce an organoleptically, nutritionally and acceptable breakfast cereal granola.

\section{References}

[1] Association of Official Analytical Chemists (AOAC), 1990. Official Method of Analysis, 17th Edition. Washington DC, USA.

[2] Anneliss Eaigster (2009). Physicochemical and sensory properties of resistant starch based cereal products and effects on postprandial glycemic and oxidation stress responses in Hispanic women. J Nutr. 27: 23-30.

[3] Aranco, R. N. (1999). Asia-Pacific Forestry Sector Outlook Study: Asiedu, J. J., 1989. Processing tropical Crops - A Technological Approach. The Macmillan Press Ltd.

[4] Barrett, A., Cardello, A., Maguire, P., Richardson, M., Kaletunc, G. and Lesher, L. (2002). Effects of sucrose ester, dough conditioner and storage temperature on long-term textural stability of shelf-stable bread. Cereal Chemistry 79: 806-811.

[5] Eke J. (2006): Chemical, functional and pasting properties of starch and tapioca produced from selected hybrid cassava (manihot esculenta crantz) cultivars. Unpublished Ph. D Thesis. 
[6] Food and Agricultural Organization (FAO), 2009. Economic and Social Department: The Statistical Division.

[7] Finney, K. F (1994). Contribution of individual chemical constituents to the functional (bread making) properties of wheat in cereals 78 better Nutrition for the World Million Minnesota. American Association of Cereal Chemist Inc.

[8] George Pamplona-Roger and Ester Malaxetxebarria (2003). Recipes for Healing and Prevention. $3^{\text {rd }}$ Edition in English.

[9] Grimwood, B. E. (1975) Coconut Palm Products. FAO, Rome.

[10] Hari, P. K, Gargs, S; Garys, S. K (1989). Gelatinization of starch and modified starch. Starch 41(3): 88-91.

[11] Houssou, P. and G. S Ayemor (2002). Appropriate processing and food functional property of maize flour. African Journal of Science and Technology 3: 126-131p.

[12] Jelfrey, A. Gwirts and Maria Nieves Garcia-Casal (2011). "Processing maize flour and corn meal food product." Department of Grain Science and Industry Kansa State university Kansa. J. Food Science and technology. 28: 39-45

[13] Kulkarni, k. D, kulkarni, D. N and Ingle, U. M. (1991): "Sorghum malt-based weaning formulation, preparation, functional properties and nutritive Values". Food and nutrition bulletin 13(4): 322-327.

[14] Kurup G. T. (1994). Tuber crop starches central Tuber crops Research Institute Sreekariyam. Thiruvananihapuram, Kerala India. Tech Bulletin series 18.

[15] Larmond, E., (1977): Laboratory methods for sensory Evaluation of food, Canda Pept Agric-Pub.

[16] Mahgoub, S. E. O., (1999). "Production and evaluation of hydrolysate from an oilseed flour mixture. Food weaning foods based on sorghum and legumes" Chem., 106: 11661174. Plants Foods Hum. Nutr. 54: 29-42.

[17] Muhammed Madeem, Salim-ur-Rahman, Faqir Muhammad Anjum, Mian Anjum Murtaza and Ghulam Mueen-ud-Din (2012). "Development characterisation and optimization of protein level in Date Bars using Response Surface Methodology". Institute food Sc \& Nut. University of Sargodha, Sargodha, Pakistan J. food science 50: 19-24.

[18] Narayana, K and Narasinga, Rao M. S (1984): Effect of partial proteolysis on the functional properties of winged pea (Psophocapustetragonolobus) flour. Journal of Food Science, 49: 944-947.
[19] Niba LL, Bokanga MM, Jackson FL, Schlimme D, Li BW (2001) Physicochemical properties and starch granular characteristics of flour from various manihot esculeata genotypes. J. Food Sci. 67: 51-56.

[20] Paniappan G. C (2002). Chemical compositions, antioxidant capacities and antiproliferative activities of coconut flours. $J$. Agric. Food. Chem. 54: 3773-3778.

[21] Richard; J. R, Asaoka M. A, Blanshard J. M. V (1991). The physico-chemical properties of cassava starch. Trop. Sci. 31: 189207.

[22] Safo-Kantanka K. O, Acquistucci R (1996). The physicochemical properties of cassava starch in relation to the texture of cooked root. Ghana J. Agric. Sci. 28 (29): 69-90.

[23] Steel, R. G. D and Torrie, J. H (1980): Principles and procedures of statistics. MC Graw Hill Pub. Comp. Inc. New York UNE (Una Norma Espanola). (1974). 34-074-74.

[24] Sosulski, F. N. (1962): "The centrifugal method for determining flour absorptivity chemistry 39 : 344-346. State University Ames, Iowa.

[25] Takashi, S. and Sieb, P. A. (1988): Paste and gel properties of prime corn and wheat starches with and without native Lipids". Cereal chemistry 65: 474-475.

[26] Tizazu H., Emire S. A (2010). "Chemical composition, physicochemical and functional properties of Lupin (Lupinusalbus) seed grown in Ethiopia". African Journal of Food, Agriculture, Nutrition and Development. 10(8). Pp 3029-3046.

[27] Trimidad PT., H. Y Divinagracia, C. M. Aida, C. A Faarida, S. M Angelica, T. C Modesta, C. A. Askali, A. S Loyola and D. B Masa (2001) "Coconut flour from residue: A good source of Dietary fibre”. Indian coconut journal Nutr. 26: 430-435.

[28] Watson S. A (1987): Structures \& Composition pp 33 - 80. In Watson S. A and Ramstad R. E (Ed) Corn Chemistry and Technology Am Soc. Cereal chem. 68: 372-378.

[29] Williams, P. C. Kuzina, F. D. and Hlynka, I. A. (1970): "A rapid calorimetric procedure for estimating he amylase content of starches and starch". Cereal Chemistry 47(4): 411-413.

[30] Zhao Z. Y, K Glassman, V. Sewalt, N Wang, M. Miller, S. Chang, T. Thompson and Y. Jung (2003). Nutritionally improved transgenic sorghum. In: Vasil I. K. (ed) Plant biotechnology 2002 and beyond. Kluwer Academic Publishers, Dordrecht, pp 413. 